\title{
From a Local
}

\section{Erfahrungsgeschichte of}

\section{Holodomor to a Global History}

\section{of Famines}

\section{Roundtable on Soviet Famines}

TA N A PENTER

In German historiography, the Ukrainian famine has not received adequate attention. A few exceptions exist, such as the 2004 special issue of the journal Osteuropa edited by Gerhard Simon and Rudolf Mark, but no single monograph in the German language nor any research project deals with the Holodomor. Moreover, amongst the broader German public, the Soviet famine of $1932-3$ is relatively unknown, despite being one of the great catastrophes in twentieth-century European history and (in terms of its death toll) one of the biggest single crimes of Stalinism. How can this obvious omission on the part of German academic researchers of Stalinism be explained?

In part it can be explained by historiographical chronology. In the I980s the publication of Robert Conquest's book Harvest of Sorrow - the book that brought greatest public attention to the Ukrainian famines in the mainstream British and US press, coincided with the German 'Historians' Dispute' (Historikerstreit) of I9867 that focused on the singularity of the Holocaust. This debate, which garnered considerable media attention, was initiated by an article written by Ernst Nolte, in which he argued that the murder of class enemies by the Bolsheviks was the 'logical and factual precedent' to the racial murder of the National Socialist regime. For Nolte the Gulag, Auschwitz, and the deportations and the mass death of kulaks in connection with Soviet collectivisation were comparable phenomena. The millions of Ukrainian famine victims did not figure in at all in the discussion among leading German historians.

But, as Guido Hausmann has recently argued, there might even exist a longer tradition of ignorance and lack of public discussion in Germany with regard to the Soviet collectivisation famines. Even in the I930s they never became a focus of concern amongst the German public, although diplomats like Gustav Hilger, a member of the German embassy in Moscow, travelled through parts of Ukraine in I932 and recognised and noted the precursors of the catastrophe. Partly due to Soviet 
policies of secrecy and partly due to the Nazi takeover in Germany in I933, the mass starving in Ukraine (as well as in other parts of the Soviet Union) did not receive widespread public attention.

Thanks to the opening of the former Soviet archives, a large number of documents on the Ukrainian famine have been published since the I990s in Ukraine and abroad. Yet, at the same time, the general discussions among academics focused and often still focuses on the genocide question, as well as the question of Stalin's intentions, whereas there is an almost complete lack of empirical research into many other important questions.

With regard to the genocide question, new research that historicises the drafting and enacting of the United Nation's Genocide Convention shows the political instrumentalisation of the term and definitions of 'genocide' during the Cold War. In his new book The Soviet Union and the Gutting of the UN-Genocide Convention, Anton Weiss-Wendt has shown how in the midst of Cold War ideological struggles the political aims of the superpowers rendered the convention a weak instrument for addressing abuses against human rights. At that time the Soviet Union wanted to keep both the famine victims and the vast system of labour camps out of the genocide discourse. The United States, for its part, feared that the Convention could be used against them in relation to the plight of African Americans. As Alexander Etkind shows in this roundtable, a closer look at Raphael Lemkin's biography and development of thoughts and ideas around genocide in the context of the Ukrainian famines, can also be quite helpful for developing new ideas on the topic.

Apart from these questions of intention and interpretation, studying regional and local micro-histories of the famine should be a priority for future research. We still don't have a clear picture of the practices of the famine in different Ukrainian regions or the role of the local and regional actors. So far, our knowledge about the geography of the Holodomor seems to be more or less limited to the recognition of considerable differences in mortality rates between different regions (oblast), but also between different administrative divisions on the lower district level (raions) within the same oblast. Regions where there was no grain surplus were less of a focus in the grain requisitions, and this played a major role in the lower death rates within them. Having said this, the phenomenon cannot fully be explained by factors such as grain surplus and vegetation.

The following section will explore in more depth the example of the Donbas, an industrial region next to the forested Chernihiv oblast, and the region with one of the lowest famine mortality rates in Ukraine. At the height of the famine in I933 the mortality rate in the Donbas was half the average death rate in Ukraine at that time. As a showcase region of the Stalinist industrialisation project, even during the famine years inhabitants of Donbas received the highest food rations. According to the central food supply plans and statistics, the urban population in the Donbas even received higher bread rations than the inhabitants of Moscow or Leningrad. This did not mean that the Donbas urban population did not suffer from the famine at all, as rations always depended on the individual utility of the worker for the socialist construction project. However, in general, the rural population in the Donbas profited from the 
higher bread rations given to the urban workers, as many peasant families had relatives working in the coal mines. Most interestingly, mortality rates differed significantly across the different rural districts of the Donbas, which leads to the assumption that, in addition to the general factors, the individual actions of local and regional actors also played an important role. In some areas local and regional party leaders hid peasant starvation from higher party authorities and did not take any measures to combat the famine for fear of being repressed themselves. In other places local actors tried to stop the starving. In one village, for example, a party secretary organised effective support for the collectivised farm workers (kolkhozniki), but only for the communists, not for the non-party members. In another village a party secretary organised help for all peasants and successfully managed to keep the mortality rate low. In some villages instances of cannibalism were reported, which were often carefully investigated by the secret police, the State Political Directorate. Hiroaki Kuromiya has shown that protests of party cadres and workers' strikes increased significantly during the famine years in the Donbas, indicating a certain culture of resistance and protest. Generally, the famine reports of the party district (raion) committees show that all groups of the rural population were likewise affected by starvation, from stigmatised kulaks to the decorated kolkhos workers who overfilled production norms, and even kolkhoz chairmen. Ethnic affiliation made no difference: Greek, German and Russian peasants suffered equally to Ukrainian peasants.

These micro histories of the diverse social practices, political cultures, actors and experiences of the famine in different local and regional settings of Ukraine can open up the possibility for a new 'experiential history' (Erfahrungsgeschichte) of the famine, which also pays more attention to the individual perceptions of the famine by victims and local perpetrators. Anne Applebaum has shown in her book the great potential of these personal famine stories in oral history testimonies and memoirs. This might also add a new perspective to our understanding of the heterogeneous regional developments and antagonisms in Ukraine, still visible in Ukrainian politics today.

Research on Soviet collectivisation famines has so far mostly followed national lines, not least due to the academic development in the Soviet Union's successor states. It would certainly enlarge the perspective to look at the Holodomor in broader comparison to the famines in Kazakhstan and Russia, as Sarah Cameron and Niccolo Pianciola have argued in this roundtable. In addition, Robert Kindler's book on the famine in Kazakhstan discusses the famine as a special means or technique of bringing the Kazakhs under Soviet rule. Kindler explains the famine as a result of food requisitions, class struggle, forced sedentarisation of the nomads and collectivisation. But other than in Ukraine, where since the I99os the Holodomor constitutes an important element in Ukrainian nation building and memory culture, in Kazakhstan the famine catastrophe has so far played only a marginal role in the official historical narrative of the country. In Kazakhstan the few scholars who have argued in favour of a genocide thesis have not gained an important voice.

Future research must answer the many questions which remain in the entangled history of the Soviet famines, such as: did the famine crisis in Kazakhstan, which 
began already in the fall of I930, serve as a 'model' for Stalin's policy in Ukraine, as some researchers have argued? Did the Soviet famine policy in Central Asia include a colonial element in contrast to the policy in Ukraine? What can the history of the Holodomor contribute to a global perspective on famines? Not only in the Soviet Union, but also in China and Cambodia, forced industrialisation and collectivisation in the second half of the twentieth century led to famine catastrophes, which resulted in millions of deaths, leading us to the question if famines under state socialism followed their own logics and patterns. The sinologist Felix Wemheuer has made a first attempt to combine the history of the Holodomor in Ukraine 1932-3 and 'the three bitter years' between I958 and 1962 in China, which caused more than 40 million deaths. He showed the many parallels between the preconditions and practices of Ukrainian and Chinese famines and paid considerable attention to the individual experiences and survival strategies of the affected people in both countries. Wemheuer shows that even in the handling of responsibility for the famine, the Chinese government borrowed heavily from the Soviet Union. Research on the Great Famine in China can thus inspire a fresh look on the Holodomor. In the Chinese case research has shown that directives of the centre were executed quite differently by regional and local party representatives, ranging from overeager to delayed order fulfilment, which at least partly explains the large deviations in mortality rates. Moreover, to explain the enormous dimension of the Chinese famine, factors including bureaucratic mismanagement, communication problems and incorrect information from the provinces seem to have been of crucial importance. It makes a lot of sense, then, to take a closer look at similar questions with regard to the Soviet famines.

Finally, the entangled history of famines is also reflected in the historical experiences of the affected populations. The fact that the population of Soviet Ukraine experienced at least four famines during the first half of the twentieth century - in I92 I-3 after the civil war, during the Holodomor, under German occupation in the Second World War and after the war in I946-7 - has to be better taken into account. To some extent, the selective hunger plan of the Nazi regime in Ukraine represented a kind of reversal of the Holodomor experience under Stalin because it primarily affected the population of the industrial centres and bigger cities, whereas the peasant population did not suffer to the same extent. Another important aspect, mentioned by Applebaum, is that under the Nazi occupation the German occupation press (for purely propagandistic reasons) reported on the Holodomor and other crimes of Stalinism. So, in Ukraine the first discussion of the famine as a crime of Stalinism (and so to say a first stage of de-Stalinisation) took place much earlier than, for example, in Kazakhstan, where the discussion started only half a century later. Even in Khrushchev's secret speech the collectivisation famines were not brought up and remained a secret. Does this difference explain among others the development of different memory cultures on the famine in Ukraine and Kazakhstan? Which lessons did the population of Ukraine learn from these different famine experiences? Which survival strategies were developed within families and how did the different famines figure in the family memories? How did the famine experiences under Soviet rule 
influence peoples' loyalties towards the Soviet state? These and other questions still need to be researched systematically.

As the examples here show, Holodomor historiography can fruitfully contribute to a modern global history of famines, particularly if it finally leaves aside the genocide debates and starts to fill the aforementioned desiderata and blanks with solid empirical research. 